\title{
Motivation Behind Reshoring Decisions in Manufacturing
}

\author{
William White \\ US Air Force \\ E-mail: billwhite527@gmail.com
}

\author{
Andrew Borchers \\ Lipscomb University, 1 University Park Drive, Nashville, TN 37204, USA \\ Email: Andy.borchers@lipscomb.edu (Corresponding Author)
}

\begin{abstract}
Manufacturing location decisions have significant business strategy implications and are often a contested political point (Tate, Ellram, Schoenherr and Petersen, 2013, Jensen, Malesky and Jensen, 2015). Firms are increasingly considering reshoring work either to their home or other countries (Tate, et al 2013). More importantly, many firms are now considering the design of their supply chains, including manufacturing locations, as a dynamic capability (Arlbjorn, 2014). This study investigates the factors firms consider in making decisions to reshore the location of manufacturing work. Ellram, Tate, and Petersen (2013) previously explored the factors involved in companies' decisions on where to locate manufacturing and identified 29 motivational factors. This study seeks to identify the factors considered most important and of greatest risk to manufacturers in making their decisions. These questions led to two propositions dealing with importance and risk. Based on a sample of 300 supply chain professionals the researchers tested these propositions using a fuzzy analytical hierarchy process (FAHP). The research suggests that, consistent with the literature, labor cost is in fact the most important factor in making relocation decisions. Contrary to the literature, however, currency stability (and not country risk) was the factor considered to provide the greatest risk.
\end{abstract}

Keywords: Outsourcing, Offshoring, Manufacturing, Reshoring

\section{INTRODUCTION}

Reshoring, or the reversal of offshoring decisions, is not a new phenomenon. However, the practice started gaining more public attention during the 2012 presidential election campaign (Tate, 2014). This attention has only grown in the 2016 election cycle. The trend towards reshoring (sometimes known as backshoring or inshoring) has been increasing since 2005. Research by Ellram, Tate, and Petersen (2013) identified a set of 29 motivating factors behind manufacturing location decisions. The relative importance of these factors, however, is unclear in the existing literature. This study seeks to extend Ellram et al. work by studying supply chain professionals to rank the importance and perceived risk of these 29 motivating factors and then to compare these ranking to expectations from academic research.

Manufacturing location decisions have significant business strategy implications and are often a contested political point (Tate, Ellram, Schoenherr and Petersen, 2013, Jensen, Malesky and Walsh, 2015). After years of outsourcing to low labor cost countries and for a variety of reasons, firms are increasingly considering moving work back home or to other countries (Tate, et al, 2013). Tate points out that the allure of low labor costs has given way to rapidly rising labor rates and the realization that firms are trapping expensive inventories on slow moving ships. More importantly, firms are now considering the design of their supply chains as a dynamic capability (Arlbjorn, 2014) with ongoing changes to where they source production. The oft drawn picture of US firms offshoring production to low labor cost foreign countries is no longer that of a oneway street. Firms are now taking a more nuanced view of where they produce products.

By understanding the motivations of the reshoring decision, researchers may be able to predict future trends in manufacturing locations. Industry leaders and company decision-makers may also garner fresh insights into the decision-making of others. These insights may help leaders consider more options when they are making manufacturing location decisions. Leaders can also compare these motivations to the documented results of competitor's reshoring activities. For example, Crooks (2012) reported that General Electric announced plans to invest $\$ 1$ billion in reshoring appliance manufacturing from locations in China back to the United States. Practitioners in other firms will watch the results carefully and, if General Electric is successful, practitioners may wish to emulate the investment. By understanding the motivations behind reshoring decisions, and seeing results from not only competitors but also other business leaders, company decision-makers may be able to find a strategic advantage by reshoring manufacturing.

\section{LITERATURE REVIEW}

In the 1970s, a new managerial strategy called offshoring emerged (Roza, Van den Bosch, \& Volberda, 2011). Offshoring, or relocating business activities to 
foreign locations, allowed companies to take advantage of extremely low-cost labor and favorable tax benefits. While offshoring was not a panacea for all businesses, the practice has remained popular for many decades. Harms, Lorz, and Urban (2012) noted how offshoring individual steps of the supply chain, and possibly nearly the entire production chain, could yield substantial savings on transportation costs as well as labor costs. Harms et al. were not alone when it came to researching offshoring and the potential resulting benefits. Housman, Kurz, Lengermann, and Mandel (2011) noted a bias in the economic analysis of many US firms. Houseman et al. determined that offshoring activities hid some additional costs created by offshoring activities. The research of Houseman et al. underpinned the criticality of understanding the effects of the global economy beyond the individual company. Offshoring is still a very popular and viable alternative. Offshoring, however, is not always the best option and firms may choose to reverse their offshoring decisions.

Even though researchers have documented reshoring activities since the 1980s (Fratocchi, Di Mauro, Barbieri,
Nassimbeni, \& Zanoni, 2014), the growing trend of reshoring since 2010 brought even more attention to the activity (Holden, 2012; Tate, 2014). While researchers have sufficiently documented the trend towards reshoring, the motivations behind the decisions to reshore are less clear. Kinkel (2012) called for further research on the influencing environmental factors leading to reshoring decisions while Arlbjørn and Mikkelsen (2014) highlighted the need for more research on the motivations for reshoring. Ellram et al. (2013) studied the motivating factors behind manufacturing location decisions, identifying 29 motivational factors influencing manufacturing location decisions. Ellram et al. used factor analysis to consolidate their 29 factors into eight groups that this study refers to as "dimensions". The dimensions were input/product, cost, labor, logistics, supply chain interruption risk, strategic risk, country risk, and government trade policies. Ellram et al. arranged the 29 motivational factors under the appropriate dimensions as shown in Table 1 below.

Table 1 Factors for relocation decision dimensions (shows 29 factors and 8 dimensions)

\begin{tabular}{|c|c|c|c|}
\hline Dimension & Factor & Dimension & Factor \\
\hline \multirow{3}{*}{ Input/product } & Currency Stability & \multirow{4}{*}{ Strategic access } & Market potential \\
\hline & Weight & & Customer presence \\
\hline & Raw materials location & & Access to supplier or buyer knowledge \\
\hline \multirow{3}{*}{ Cost } & Switching cost & & Competitive pressure \\
\hline & Labor cost & \multirow{6}{*}{ Country risk } & Global/political uncertainty \\
\hline & Stability of labor cost & & Environmental issues \\
\hline \multirow{2}{*}{ Labor } & Availability of local management & & Social/ethical \\
\hline & Availability of labor & & Natural disaster \\
\hline \multirow{4}{*}{ Logistics } & $\begin{array}{r}\text { Availability of knowledge } \\
\text { intermediaries }\end{array}$ & & Political instability \\
\hline & Availability of transportation & & Regulation risk \\
\hline & Stability of transportation cost & \multirow{5}{*}{$\begin{array}{c}\text { Government trade } \\
\text { policies }\end{array}$} & Tax advantages \\
\hline & Transportation reliability & & Subsidies \\
\hline \multirow{3}{*}{ Supply chain interruption risk } & Distance to customer & & Countertrade requirements \\
\hline & Terrorism & & \\
\hline & Disaster & & \\
\hline
\end{tabular}

Note. Adapted from "Offshoring and reshoring: An Update on the Manufacturing Location Decision." by L. Ellram, W. Tate, \& K. Petersen, 2013, Journal of Supply Chain Management, 49, p. 17.

This research seeks to identify which factors are most important in reshoring decisions and which factors are the greatest sources of risk. Prior research by Atherton (2014) showed that in their sample increased capital and reduced employment costs rank at the top of the list of motivations to consider offshoring. Similarly, Arlbjørn and Mikkelsen (2014), Deligio (2014), and Kinkel (2014) all highlight the costs associated with relocation as primary motivating factors. Reduced labor cost, increased transportation costs, and tax implications are all cost related factors. Hence, if cost is the most important factor in offshoring in the first place, it stands to reasons that cost should be the most important factor in reshoring.

When companies evaluate potential risks, country risks are noted among the top considerations. Rice and Stefanelli (2014) identified several country risks increasing the attractiveness of reshoring. Cultural differences, transportation and distribution issues, and international tax laws, all influence the risks companies take when conducting offshore manufacturing in the first place. Again, this being the case it stands to reason that country risk should be the greatest source of risk in reshoring.

\section{RESEARCH AND QUESTIONS PROPOSTIONS}

The literature review above led the researchers to the following research questions:

1. Which of the 29 motivational factors, identified by Ellram et al. (2013), do manufacturers consider the most important when making manufacturing relocation decisions? 
2. Which of the 29 motivational factors, identified by Ellram et al., do manufacturers consider to contribute the most risk when making manufacturing relocation decisions?

These research questions and the literature above (especially Atherton (2014) and Rice and Stefanelli (2014)) led to the following propositions:

Proposition 1. The dimension of cost, consisting of the factors switching cost, labor cost, and the stability of labor costs is the most important dimension to manufacturers when making manufacturing location decisions.

Proposition 2. Companies consider the dimension of country risk, consisting of the factors global/political uncertainty, environment issues, social/ethical issues, natural disasters, political instability, and regulation risks, to have the highest level of risk when making manufacturing location decisions.

\section{NUMERICAL STUDY}

This study followed an exploratory design format. To build upon the work of Ellram et al. (2013), this study used the same survey instruments as Ellram et al. as a basis for a new survey instrument. The new survey instruments inquired about the perceptions company leaders have on the relative benefits of each of the factors influencing manufacturing relocation decisions. The study also investigated the perceived risk of each of the factors Ellram et al. identified in their study. This study emulated the approach of Ghandehary, Harati, and Javad (2014) by utilizing a Fuzzy Analytic Hierarchy Process (FAHP) approach to understanding the motivations behind manufacturing relocation decisions.

Due to the use of new survey instruments, this study started with a field test. Six experts with terminal degrees evaluated the instruments and provided feedback on validity and appropriateness of the survey. All experts agreed that the questions were reasonable and would not put participants through unnecessary distress or discomfort.

Table 2 Positions held by participants

\begin{tabular}{lll}
\hline Position & N & \% of Total \\
\hline VP or higher & 51 & $15.9 \%$ \\
\hline Director & 60 & $18.7 \%$ \\
\hline Manager & 107 & $33.3 \%$ \\
\hline Individual Contributor & 54 & $16.8 \%$ \\
\hline Other & 49 & $15.3 \%$ \\
\hline Total & 321 & \\
\hline
\end{tabular}

Table 4 Annual sales of firms represented in sample

\begin{tabular}{lll}
\hline Annual Sales & $\mathbf{N}$ & $\%$ \\
\hline Over $\$ 40 \mathrm{~B}$ & 24 & $7.4 \%$ \\
\hline$\$ 10-\$ 39.9 \mathrm{~B}$ & 29 & $9.0 \%$ \\
\hline$\$ 2-9.9 \mathrm{~B}$ & 47 & $14.5 \%$ \\
\hline$\$ 500 \mathrm{M}-1.9 \mathrm{~B}$ & 65 & $20.1 \%$ \\
\hline \$100 M - \$499 B & 57 & $17.6 \%$ \\
\hline Less than \$100 M & 65 & $20.1 \%$ \\
\hline Choose not to answer & 37 & $11.4 \%$ \\
\hline Total & 324 & \\
\hline
\end{tabular}

Afterwards, the survey entered into a pilot study. This study obtained data via an electronic survey distributed and collected by Qualtrics, a professional data collection company with access to panels of individuals meeting the study criteria. The pilot study consisted of 25 individuals and tested the validity and reliability of the survey instruments. The individuals for the pilot study met the same criteria as the main study. This data was separate from the larger survey and did not influence the results of the main study. Once the pilot study was complete, the survey proceeded as scheduled through Qualtrics. The survey allowed respondents to rank order factors in terms of perceived importance and risk. The final survey included eight questions: one question to rank importance, one question to rank risk and a set of six (6) demographic questions described in the following paragraphs.

Three demographic questions were used to qualify participants as being manufacturing and production industry professionals with recent (past three years) experience in offshoring or reshoring. These questions also qualified their understanding of the term "off shoring". Qualtrics queried their preselected panels of individuals within the parameters of this study until 300 respondents replied. The 300 responses ensured an adequate sample to draw some conclusions about a potential relationship between the perceived importance of the motivating factors and the perceived risk of the motivating factors.

The other three demographic questions provided information about the sample. Participants held a wide range of positions in various functional areas and with firms of various sizes. Table 2 demonstrates that the sample included a broad cross section of manufacturing professionals. Survey participants came from a number of functional areas within their firms. Table $\mathbf{3}$ demonstrates this distribution and shows a broad range of functional areas. Finally, participants came from various sized organizations. Table 4 shows a distribution of the annual sales for the firms represented in the sample. Again, this table demonstrates the breadth of the sample.

Table 3 Functional areas represented

\begin{tabular}{lll}
\hline Functional Area & $\mathbf{N}$ & $\%$ of Total \\
\hline Engineering & 51 & $16.1 \%$ \\
\hline Finance & 45 & $14.2 \%$ \\
\hline Logistics & 54 & $17.1 \%$ \\
\hline Supply / Purchasing & 35 & $11.1 \%$ \\
\hline Marketing & 15 & $4.7 \%$ \\
\hline Other & 116 & $36.7 \%$ \\
\hline Total & 316 & \\
\hline
\end{tabular}

The survey yielded different ranking weights to each of the factors and the related dimensions. The study then utilized FAHP to rank the motivators by factor and dimension. Furthermore, the study provided similar rankings depicting the factors manufacturers perceive to add the most risk to relocation decisions 


\section{FINDINGS}

Survey results answered the first research question and related proposition by indicating that among survey participants the factor of labor cost and the entire cost dimension are in fact the most important factors influencing manufacturing relocation decisions. The results also support the first proposition, which suggested that cost is the most important dimension to manufacturers when making manufacturing location decisions. The survey suggested this proposition is accurate as cost ranked first among the dimensions (Table 5).
The second research question and related proposition asked which factor decision makers believed held the most risk. The survey data showed that survey participants found the factor of currency stability and the input/product dimension offered the most risk to decision makers. This did not support the second proposition, which (based on Rice and Stefanelli (2014)) suggested companies consider the dimension of country risk to have the highest importance when making manufacturing location decisions. The survey results showed that the input/product dimension (which includes the factor of currency stability) ranked as the top risk dimension (Table 6).

Table 5 Dimension rankings based on weight of importance

\begin{tabular}{ccr}
\hline Rank & Weight & Dimension (Factors) \\
\hline 1 & 1.4933 & Cost (Labor cost 2.24, switching 1.45 and stability .7933) \\
\hline 2 & 1.3033 & Input/product \\
\hline 3 & 0.8067 & Labor \\
\hline 4 & 0.4242 & Logistics \\
\hline 5 & 0.2533 & Sovernment trade policies \\
\hline 6 & 0.2389 & Supply chain interruption \\
\hline 7 & 0.1833 & Country risk \\
\hline 8 & 0.1334 &
\end{tabular}

Table 6 Dimension rankings based on weight of perceived risk

\begin{tabular}{crr}
\hline Rank & Weight & \multicolumn{2}{c}{ Dimension } \\
\hline 1 & 0.9922 & Input/product (currency stability 1.57, location of raw material \\
& & 1.33 and product weight 1.00) \\
\hline 2 & 0.9822 & Cost \\
\hline 3 & 0.6900 & Labor \\
\hline 4 & 0.4775 & Sogistics \\
\hline 5 & 0.4100 & Supply chain interruption \\
\hline 6 & 0.3828 & Country risk \\
\hline 7 & 0.3050 & Strategic Access \\
\hline 8 & 0.2100 & Government trade policies \\
\hline
\end{tabular}

\section{DISCUSSION}

Of the ten factors making up the top five importance and risk factors in the two propositions, it is interesting that the dimensions of input/product and cost account for all but one of the ten factors. In addition, the survey results indicate that the factors most important to manufacturing relocation decisions are among the riskiest factors. The study further indicates that industry leaders recognize the risk factors, identify them as important to the relocation decision, and properly weighed the alternatives prior to deciding on a course of action.

Ellram et al. (2013) studied the motivations behind the reshoring decisions of manufacturing jobs. This study furthered the study of Ellram et al. in an attempt to identify the most important factors in the decision to relocate manufacturing and identify the factors manufacturers perceive to provide the highest level of risk. As expected, labor cost is the most important factor in making relocation decisions. Surprisingly, country risks, as noted in proposition 2 , did not rate very high in reference to overall risk.

In conclusion, manufacturing location is a key strategic decision for firms and generates significant discussion in the political world. The results of this study can help manufacturing leaders think about important and risk related factors they may have missed in their own analysis. Full and detailed analysis that accounts for these factors, prior to making relocation decisions, can help companies increase their profit margin and ensure their viability.

\section{REFERENCES}

Arlbjørn, J., \& Mikkelsen, O. (2014). Backshoring manufacturing: Notes on an important but under-researched theme. Journal of Purchasing and Supply Management, 20(1), pp. 60-62. doi:10.1016/j.pursup.2014.02.003.

Crooks, E. (2012). GE takes $\$ 1$ bn risk in bringing jobs home. Financial Times. Available from http://www.ft.com/cms/s/0/21a46546-78f1-11e1-88c500144feab49a.html 
Ellram, L., Tate, W., \& Petersen, K. (2013). Offshoring and reshoring: an update on the manufacturing location decision. Journal of Supply Chain Management, 49(2), pp. 14-22. doi:10.1111/jscm.12019

Fratocchi, L., Di Mauro, C., Barbieri, P., Nassimbeni, G., \& Zanoni, A. (2014). When manufacturing moves back: Concepts and questions. Journal of Purchasing and Supply Management, 20(1), $\quad$ pp. doi:10.1016/j.pursup.2014.01.004.

Ghandehary, M., Harati, H., \& Javad, K. (2014). Identifying and ranking the effective factors on customer values. Education, Business and Society: Contemporary Middle Eastern Issues, 7(1), pp. 57-74. doi:10.1108/EBS-04-2013-0009

Harms, P., Lorz, O., \& Urban, D. (2012). Offshoring along the production chain. Canadian Journal of Economics, 45(1), pp. 93-106. doi:10.1111/j.1540-5982.2011.01688.x

Holden, G. (2012). U.S. manufacturers coming home? Research Technology Management, 55(5), 4-6. Available from http://www.economist.com/news/special-report/21569570growing-number-american-companies-are-moving-theirmanufacturing-back-united

Houseman, S., Kurz, C., Lengermann, P., \& Mandel, B. (2011). Offshoring bias in U.S. manufacturing. The Journal of
Economic Perspectives, 25(2), pp. 111-132. doi:10.1257/jep.25.2.111

Jensen, N. M., Malesky, E. J., \& Walsh, M. (2015). Competing for global capital or local voters? The politics of business location incentives. Public Choice, 164(3-4), pp. 331-356.

Kinkel, S. (2012). Trends in production relocation and backshoring activities. International Journal of Operations \& Production Management, 32(6), pp. 696-720. doi:10.1108/01443571211230934

Roza, M., Van den Bosch, F., \& Volberda, H. (2011). Offshoring strategy: Motives, functions, locations, and governance modes of small, medium-sized and large firms. International Business Review, 20(3), pp. 314-323. doi:10.1016/j.ibusrev.2011.02.002.

Tate, W. (2014). Offshoring and reshoring: U.S. insights and research challenges. Journal of Purchasing and Supply Management, 20(1), pp. 66-68. doi:10.1016/j.pursup.2014.01.007.

Tate, W. L., Ellram, L. M., Schoenherr, T., \& Petersen, K. J. (2014). Global competitive conditions driving the manufacturing location decision. Business Horizons, 57(3), pp. 381-390.

Bill White, DBA, is a senior arms control treaty analyst supporting the USAF in Washington DC. Before working as a treaty analyst, Bill enjoyed a 20 year career in the Air Force working in intercontinental ballistic missile operations and international arms control, retiring with the rank of Lieutenant Colonel.

Andy Borchers, DBA is a Professor of Management and Chair of the department of Management, Entrepreneurship and Marketing at Lipscomb University in Nashville, TN. Before moving to Lipscomb in 2011, Andy spent 20 years in the auto industry and taught at Lawrence Technological University and Kettering University. His teaching and research interests cover a broad range of computing and business subjects including enterprise systems, analytics, databases, environmental sustainability and entrepreneurship. 